\title{
Wound repair and scarring of genital skin
}

\author{
Ursula Mirastschijski ${ }^{1,2}$, Dongsheng Jiang ${ }^{3}$, Yuval Rinkevich ${ }^{3}$, Refaat Karim ${ }^{4}$, Heiko Sorg ${ }^{5,6}$ \\ ${ }^{1}$ Center for Biomolecular Interactions Bremen, University of Bremen, Bremen 28359, Germany. \\ ${ }^{2}$ Mira-Beau gender esthetics, Berlin 10777, Germany. \\ ${ }^{3}$ Comprehensive Pneumology Center, Institute of Lung Biology and Disease, Helmholtz Zentrum München, Munich 85764, \\ Germany. \\ ${ }^{4}$ A kliniken, Amstelveen 1182, The Netherlands. \\ ${ }^{5}$ Department of Plastic, Reconstructive and Aesthetic Surgery, Klinikum Westfalen, Dortmund 44309, Germany. \\ ${ }^{6}$ Department of Health, Faculty of Medicine, University Witten/Herdecke, Witten 58455, Germany.
}

Correspondence to: Prof. Ursula Mirastschijski, Center for Biomolecular Interactions Bremen, University of Bremen, Leobener Str/NW2, Bremen 28359, Germany. E-mail: mirastsc@uni-bremen.de

How to cite this article: Mirastschijski U, Jiang D, Rinkevich Y, Karim R, Sorg H. Wound repair and scarring of genital skin. Plast Aesthet Res 2020;7:70. http://dx.doi.org/10.20517/2347-9264.2020.147

Received: 7 Jul 2020 First Decision: 17 Sep 2020 Revised: 12 Oct 2020 Accepted: 10 Nov 2020 Published: 5 Dec 2020

Academic Editor: Alexis Desmoulière, Raúl González-García Copy Editor: Cai-Hong Wang Production Editor: Jing Yu

\begin{abstract}
Aim: Scarring is a physiological process in adult wound repair. Although keratinocytes and fibroblasts are the main cell types of the skin, they differ in migration behaviour and inflammatory responses depending on their location in the body. The aim of this article is to describe wound repair in genital skin and to depict differences with regard to skin anatomy and cellular responses to inflammatory stimuli in acute and chronic wound healing.
\end{abstract}

Methods: This report reviews data from patients undergoing reconstructive and aesthetic plastic surgery as well as published studies on genital wound repair. Genital surgery comprised plastic reconstructive surgery after urological interventions of biological men and women, tissue from trans-males and trans-females undergoing gender reassignment surgery and tissue from patients undergoing aesthetic genital surgery. The cohort comprised a total of 68 patients ( $32.9 \pm 11.3$ years), of which 31 were male (mean $30.4 \pm 9.3$ years) and 37 were female ( $34.9 \pm 12.5$ years; mean \pm SD).

Results: Wound healing in genital skin markedly differs from other areas of the body due to its anatomical features, microbiome, and elevated hormonal responsiveness. Human genital skin is highly extensible and unusually rich in elastic fibres, and it lacks the mechanical anchorage and tensile properties typical of non-genital regions. Acute injury resolves rapidly due, in part, to rapid resolution of the inflammatory response. In contrast to scarring responses on other body surfaces, genital skin wounding is resolved by shrinkage or fistula formation.

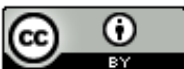

(C) The Author(s) 2020. Open Access This article is licensed under a Creative Commons Attribution 4.0 International License (https://creativecommons.org/licenses/by/4.0/), which permits unrestricted use, sharing, adaptation, distribution and reproduction in any medium or format, for any purpose, even commercially, as long as you give appropriate credit to the original author(s) and the source, provide a link to the Creative Commons license, and indicate if changes were made.

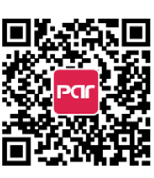


Conclusion: The embryological origins of genital skin fibroblasts, together with the gender-specific hormonal environment, contribute to the unique phenotype and healing properties of genital skin. When performing genital surgery, it is of utmost importance to be aware of the differing responsiveness of genital tissue to trauma, surgery, and repair.

Keywords: Genital skin, hormone sensitivity, shrinkage, scarless, oestrogen, testosterone

\section{INTRODUCTION}

The skin is our largest organ, consisting of a variety of cells, layers, adnexa such as hair follicles, sebaceous and sweat glands, and with nerve endings sensing pain, pressure, vibrations and temperature. All these entities act in concert to sense and to protect us against the outside world, e.g., physical, chemical and biological influences (temperature, radiation, desiccation, trauma, chemicals, microbia, etc.). Furthermore, the skin is of utmost importance for us to perceive our environment and for communication. Our skeleton and the musculature provide the inner framework, which the skin covers as outer surface. The elasticity and robustness of the skin are optimized for growth, joint motion and shear and tear.

As stated above, the integrity of our outer envelope is the prerequisite for survival. A whole body of literature and knowledge is available on the physiology of skin wound healing and scarring as summarized in this PAR issue. Interestingly, little is known on the anatomical features and pathophysiology of genital wound repair. This may be due to the fact that trauma to the genitalia is rare with only $5.3 \%$ of combat ${ }^{[1]}$ or $1.5 \%$ of burn injuries ${ }^{[2]}$ afflicting the genital area. In contrast, infections are quite common. With the commensal microbial colonization of the vagina, urinary orifices or anus, the genital skin is constantly exposed to a high variety of putative intruders. Minor lesions can cause bacterial penetration into deeper tissue layers and manifest as abscess, gangrene or fasciitis, also known as Fournier's gangrene with a high mortality ${ }^{[3]}$. Due to the life-threatening character of genital infections, immediate and thorough debridement is the only cure followed by defect reconstruction after recovery in an interdisciplinary setting comprising urologists, gynaecologists, and general as well as plastic surgeons.

Despite of the fact that $30 \%$ of males are circumcised world-wide, almost no data exists on genital wound healing and scarring ${ }^{[4]}$. In recent times, the number of surgical interventions for gender reassignment surgery and genital aesthetic surgery, especially labioplasty, has increased enormously with the need for more information on genital skin repair processes. It is also striking that female genital mutilation/cutting (FGM/C) patients have little to no hypertrophic scarring or keloid formation. This is in contrast to clinical observations of normal scar tissue formation in pigmented skin with a higher tendency for excessive scarring. The aim of this article is to inform on the anatomy and microstructure of genital skin, to delineate healing differences compared to skin of other body parts, and to encourage further research in this hitherto neglected area of genital skin wound repair.

\section{METHODS}

Data on genital postoperative scarring were derived from our own patient cohort with an observational period of 5 years. Pre- and postoperative examinations were performed as routine diagnostics and followups for patient care. Genital surgery comprised plastic reconstructive surgery after urological interventions of biological men and women, tissue from trans-males and trans-females undergoing gender reassignment surgery and tissue from patients undergoing aesthetic genital surgery. The cohort comprised a total of 68 patients $(32.9 \pm 11.3$ years), of which 31 were male (mean $30.4 \pm 9.3$ years) and 37 were female $(34.9 \pm$ 12.5 years; mean $\pm \mathrm{SD})$. 
Tissue specimens were obtained after information and written patient's consent. The study was approved by the local ethical committees (Ethics Committee of the Medical Chamber of Bremen, no. 336/12 and no. RA/RE 336; and of Bavaria, 2018-157). Tissues were harvested directly after surgery and fixed with $2 \%$ paraformaldehyde and processed for cryosection.

\section{Histological assessment}

For comparison of skin derived from the genitalia or from other body parts, $6 \mu \mathrm{m}$ cryosections were cut and processed as previously described ${ }^{[5,6]}$. An overview of the cutaneous microstructure is provided by hematoxylin-eosin staining as described previously ${ }^{[5]}$. For visualization of collagen fibres, Masson's trichrome staining was performed by using commercially available kit from Sigma-Aldrich (\#HT15-1KT) ${ }^{[6,7]}$. In brief, cryo-sections were fixed in cold acetone at minus $20^{\circ} \mathrm{C}$ for $5 \mathrm{~min}$ and then incubated in preheated Bouin's solution (Sigma-Aldrich HT10132) at $56{ }^{\circ} \mathrm{C}$ for $5 \mathrm{~min}$. After that the sections were sequentially incubated at room temperature in Biebrich scarlet-acid fuchsin solution for $5 \mathrm{~min}$, working concentration of Phosphotungstic/ Phophomolybdic acid for $5 \mathrm{~min}$, aniline blue solution for $10 \mathrm{~min}$, and $1 \%$ acetic acid for 2 min. After dehydration, the sections were cleared with Roti-Histol (Roth 6640) and mounted with a Roti-Histokitt (Roth 6638). Collagen was stained in blue, cells in red and nuclei in black. For elastic fibres, Elastica van Gieson staining was performed by using commercially available kit from Sigma-Aldrich (\#115974), according to the manufacturer's instruction.

\section{RESULTS}

\section{Anatomy and histology of genital skin}

Development of the outer genitalia and similarities between male and female tissues

To understand the microscopic features of the genital skin in both sexes, one has to keep in mind the common origin of the genitalia with intrauterine differentiation due to hormonal influences. The outer genital organs derive from genital buds, which develop into the penis or small labia and into the scrotum or the big labia [Table 1, Figure 1]. Consequently, the microstructure of the genitalia is like the corresponding part of the other sex, e.g., penis and small labia (labia minora) or scrotum and big labia (labia majora).

\section{Skin architecture and biomechanics}

Human skin is structured into the epidermis, the dermis and the subcutaneous fat layer. On many sites of the human body, the subcutaneous fat is divided in two compartments by a thin fascia, the fascia cutanea superficialis, also named "Scarpa fascia". The Scarpa fascia is a remnant of the carnosus muscle found in fur bearing animals. In the neck, the ancient muscle is still present as platysma and, in the genitals, as Dartos muscle in the scrotal sac or Dartos fascia in the penis or Colles' fascia in the labia. The absence of anchoring structures provided by the subcutaneous fat layer is an explanation for the highly mobile genital skin. Besides, the penis and the small labia are devoid of fat, whereas fat tissue is commonly found in the big labia and in the scrotal sac in obese men. Another unique feature of the genitalia is the fact that they are devoid of any skeletal fixation, neither to bone or cartilage structures. The biomechanics of genital organs differ from tissues with underlying anchorage to stiff structures resulting in constant biophysical strain and tension to the covering connective tissue and skin layers. The biomechanical environment and the extracellular matrix architecture of the external genitalia create a low-tension state that may contribute to reduced mechanotransduction.

\section{Microscopic structure of genital skin}

The genital epidermis differs from skin of other body parts in two main aspects, namely by being devoid of hair (penis and small labia as well as the inner aspect of the big labia), and by being, in part, covered by mucous epithelium, which does not keratinize and has no cornified layer (clitoris, glans penis, inner part of the foreskin of glans and clitoris). The dermal structure of the genitalia differs from other skin sites as well. The separation in upper, papillary dermis and lower, reticular dermis is less prominent as in non-genital 
Table 1. Skin structure of homologous male and female outer genitalia

\begin{tabular}{|c|c|c|c|}
\hline & Male & Female & Histological microstructure \\
\hline Glans & Of penis* & Of clitoris & $\begin{array}{l}\text { Multilayered, non-keratinizing epidermis, dermal tissue with abundant nerve } \\
\text { endings }\end{array}$ \\
\hline Foreskin & Of penis & Of clitoris & $\begin{array}{l}\text { Outer part: epidermis with cornified layer } \\
\text { Inner part: non-keratinizing epidermis; mucous epithelium; no fat tissue }\end{array}$ \\
\hline \multirow[t]{3}{*}{ Frenulum } & Frenulum penis & Frenula clitoridis (paired) & Non-keratinizing, mucous epithelium, no subcutaneous fat tissue \\
\hline & Penile shaft skin & Small labia & $\begin{array}{l}\text { Penis: epidermis with cornified layer, highly flexible attachment to underlying } \\
\text { tissue via Dartos fascia (Fascia penis superficialis) } \\
\text { Labia: outer surface with thin cornified layer; inner surface: no cornified layer } \\
\text { Both: no hair; no fat tissue; many elastic fibers }\end{array}$ \\
\hline & Scrotum & Big labia & $\begin{array}{l}\text { Hair bearing epidermis (labia: only outer surface), epidermal cornified layer } \\
\text { Labia: subcutaneous fat layer and smooth muscle cells } \\
\text { Scrotum: no (or very little) fat, but contractile Tunica Dartos with smooth } \\
\text { muscle cells and myofibroblasts; in obese patients: fat tissue }\end{array}$ \\
\hline
\end{tabular}

${ }^{*}$ After circumcision, the epithelium changes into a keratinizing epidermis of the glans penis

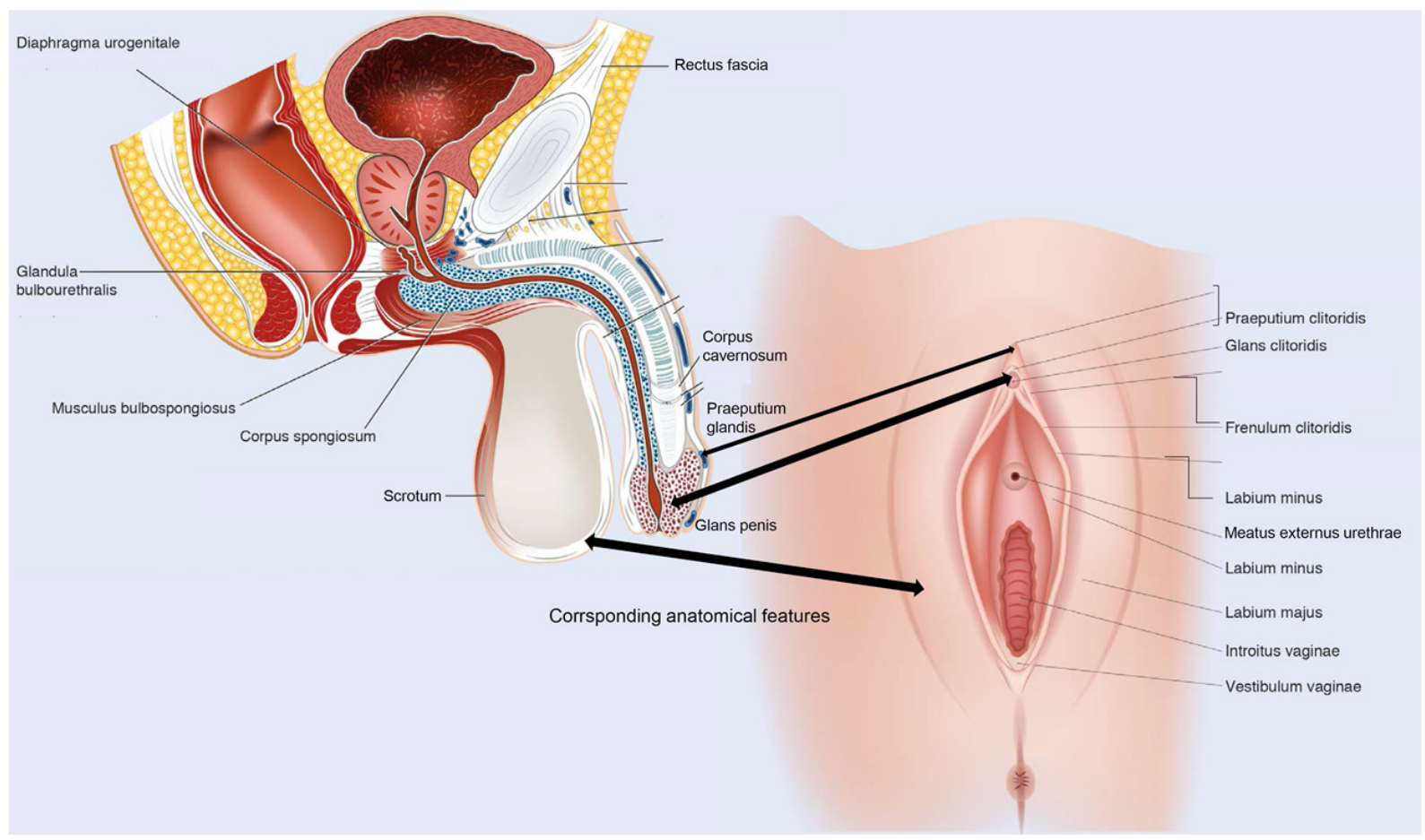

Figure 1. Comparison of corresponding anatomical features in male and female genitalia. Genital buds differentiate into penis or scrotum in males and into labia minora and majora in females respectively. Common features are the glans and the foreskin that covers the glans in both genders. In females, genital buds separate and become labia, in males genital buds fuse and become scrotum and penis. Remnants of the fusion process are seen in two parts of the septum scroti. Both septi contain their own vasculature ${ }^{[8]}$. (modified after Mirastschijski and Remmel ${ }^{[9]}$ )

skin. The genital dermal structure is more loosely woven and contains abundant elastic fibres and less collagen in comparison to other body parts [Figure 2]. High elasticity is a prerequisite for the frequent and fast changes in volume and expansion of the genital organs, e.g., during penile erection or excitement with higher perfusion and tumescence of the cavernous bodies, or for temperature regulation in the scrotal sac.

\section{Hormone responsiveness of genital skin}

Tissues and cells of genital and non-genital skin exhibit diverging expression of hormone receptors and processing of sex hormones [Table 2]. Hormone responsivity of tissues has important impact on skin wound repair ${ }^{[10]}$. Female and male hormones influence genital wound healing differently [Figure 3]. For 


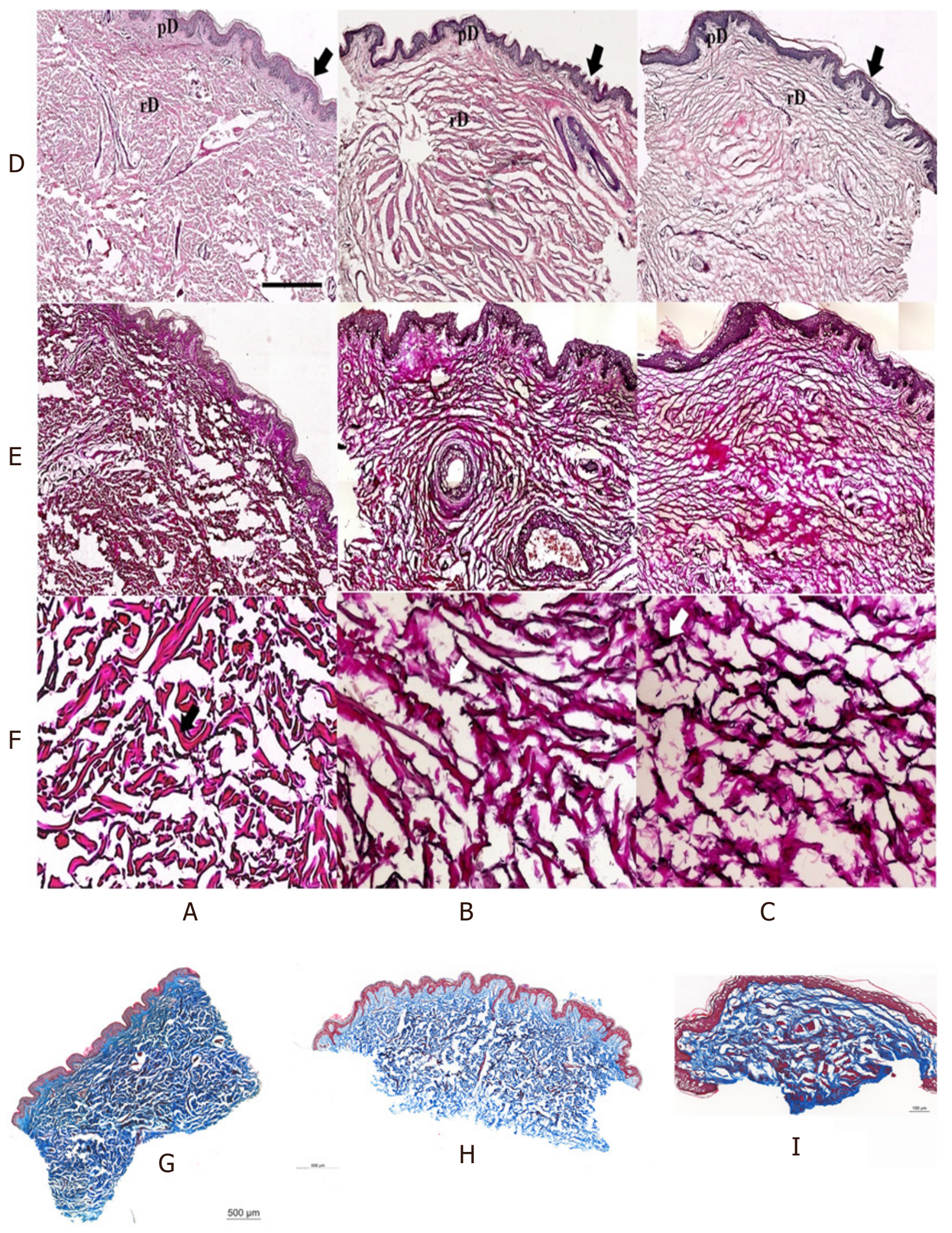




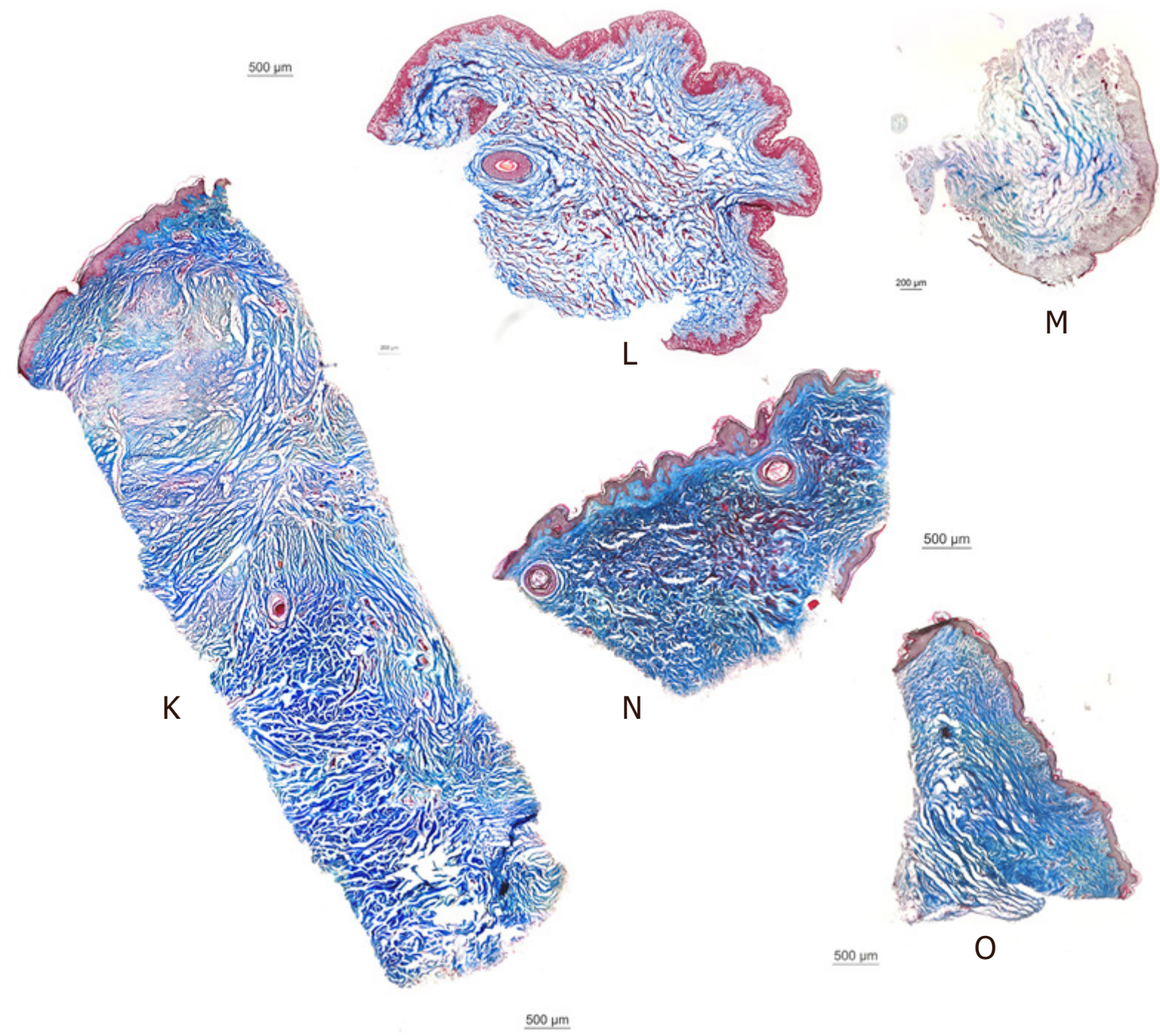

Figure 2. Microstructure of the skin from different body areas. A: lower left arm, B: penis, C: small labia. Note the dense dermal structure with multiple vessels in (A) and lose collagen bundles in (B) and (C) with high similarity of penile and labial skin. D: panel HE staining, E and F: Elastica van Gieson staining. Arrow upper panel depicting epidermis, pD papillary dermis, rD reticular dermis. Note abundance of collagen fibres in arm skin (red staining, black arrow; panel $\mathrm{E}$ and $\mathrm{F}$ ) and abundant elastic fibres in penile and labial skin (black staining, white arrows). Scale bar in A for upper two panels $500 \times m$, lower panel 40x magnification. G-O: Masson Trichrome staining for visualization of collagen fibres (blue staining) in normal and scar tissues of different origin. $G, H, I, N$ normal skin, $K, L, M, O$ scar tissue; $\mathrm{G}$ and $\mathrm{K}$ breast, $\mathrm{H}$ and $\mathrm{L}$ scrotum, I and $\mathrm{M}$ penis, $\mathrm{N}$ and $\mathrm{O}$ abdomen. Note abundant collagen bundles in normal breast and abdominal skin ( $\mathrm{G}$ and $\mathrm{N}$ ) and densely packed collagen bundles in scar tissue of breast and abdomen ( $\mathrm{K}$ and $\mathrm{O}$, respectively). Thickened dermal tissue in breast scar $(K)$. Loose connective tissue with scrotal $(H, L)$ and penile $(I, M)$ normal and scar tissue without densely packed collagen bundles as seen in non-genital scar tissue. Scale bars next to each specimen indicating magnification

example, oestrogens accelerate wound closure, whereas testosterone delays healing ${ }^{[11]}$. Skin is a major source of extra-glandular sex steroid hormones. The intracellular enzyme aromatase converts the sex hormone precursor dehydroepiandrosterone downstream into estrone or via testosterone into the more potent $17 \beta$-oestradiol. Both oestrogens act via the oestrogen receptors and stimulate keratinocyte and fibroblast migration ${ }^{[10]}$. In genital fibroblasts, aromatase expression is androgen dependent and oestrogens stimulate fibroblast contractility without increasing alpha-smooth muscle actin expression or myofibroblast differentiation ${ }^{[12]}$. Upon wounding, aromatase activity increases 400 -fold in keratinocytes with increased intracellular oestrogens. Oestrogens reduce the cellular inflammatory response via downregulation of the pro-inflammatory cytokine macrophage migration inhibitory factor ${ }^{[13]}$, by reduced toll-like-receptor-4 mediated mitogen activated protein kinase activation, by reduced macrophage infiltration into wounds and 
Table 2. Hormonal differences between genital and non-genital skin of both sexes

\begin{tabular}{|c|c|c|}
\hline & Genital skin & Non-genital skin \\
\hline Androgen receptor & $\begin{array}{l}\text { Higher expression in labia majora and minora; } \\
\text { Upregulated in fibroblasts and basal keratinocytes; } \\
\text { Co-localization with ER }\end{array}$ & $\begin{array}{l}\text { Only present in hair follicles and pilo-sebaceous duct } \\
\text { keratinocytes; } \\
\text { Low expression in extra-genital skin }\end{array}$ \\
\hline Oestrogen receptors & $\begin{array}{l}\text { Highly expressed in penis and labia minora; } \\
\text { Restricted to basal keratinocytes and stromal fibroblasts; } \\
\text { Expression decreases with age }\end{array}$ & $\begin{array}{l}\text { Lower expression compared to vulva or vagina; } \\
\text { Expressed by keratinocytes and fibroblasts; } \\
\text { Absence in skin appendages or blood vessels }\end{array}$ \\
\hline Testosterone & $\begin{array}{l}\text { AR binding capacity of Testosterone higher; } \\
30 \text { times faster degradation; } \\
\text { Reduced effect on aromatase activity in low oxygen } \\
\text { conditions }\end{array}$ & $\begin{array}{l}\text { Higher rate of conversion testosterone into DHT; } \\
\text { Higher } 5 \text { - } \alpha \text {-reductase activity with irreversible } \\
\text { formation of DHT }\end{array}$ \\
\hline Oestrogens & $\begin{array}{l}\text { No conversion of } 17 \beta \text {-estradiol into the weaker estrone; } \\
\text { Stimulate fibroblast contractility without ASMA } \\
\text { expression }\end{array}$ & $\begin{array}{l}\text { 3-fold increased metabolism of } 17 \beta \text {-estradiol into the } \\
\text { weaker estrone }\end{array}$ \\
\hline Aromatase & $\begin{array}{l}\text { Higher activity in fibroblasts with conversion of } \\
\text { testosterone into } 17 \beta \text {-estradiol; } \\
\text { Dose-dependent reduced activity by testosterone; } \\
\text { Aromatase expression is androgen dependent }\end{array}$ & $\begin{array}{l}\text { Expression in skin fibroblasts, keratinocytes of the } \\
\text { outer root sheath and in terminal hair follicles and in } \\
\text { cells of sebaceous glands and ducts }\end{array}$ \\
\hline
\end{tabular}

AR: androgen receptor; ER: oestrogen receptors; DHT: dihydrotestosterone; ASMA: alpha smooth muscle actin

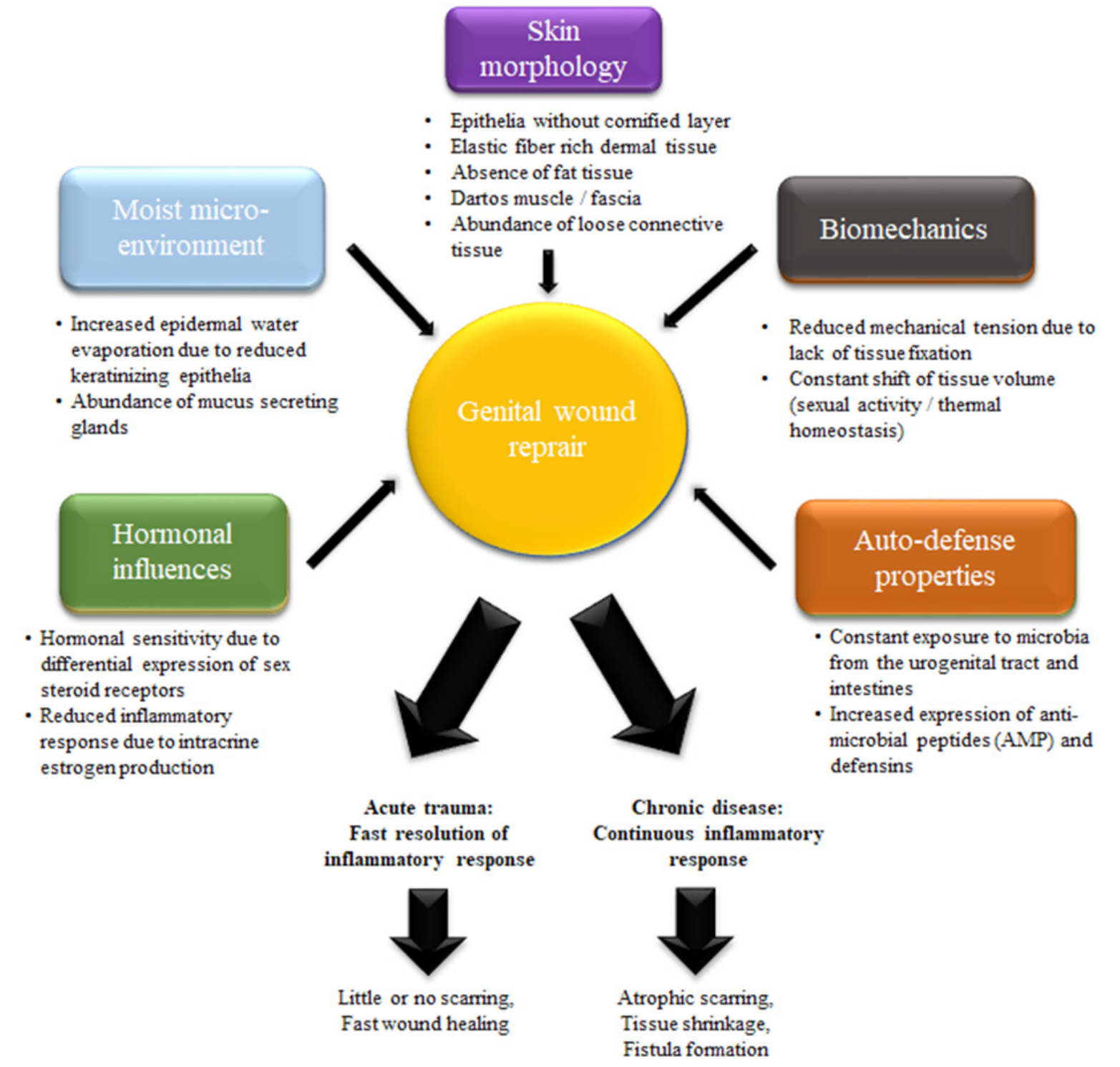

Figure 3. Genital wound repair is influenced by moisture, hormones, biomechanics, microbial environment and specific skin morphology that differs from skin of other body parts 
reduced pro-inflammatory signalling of interleukin- 6 and tumour necrosis factor (TNF)- $\alpha^{[14]}$. Furthermore, oestrogens are also important anti-oxidants that reduce cellular oxidative stress, apoptosis and increase keratinocyte migration and collagen synthesis by dermal fibroblasts ${ }^{[15]}$. In menopausal women, cutaneous oestrogen insufficiency manifests by atrophic skin changes, vulvar and vaginal exsiccation, and diminished defence against reactive oxygen species.

\section{Hormonal influences on genital skin during menopause}

As stated above, genital tissue is highly responsive to hormonal cues and changes. The menopause is a major incident in a woman's live with effects on her social, physical and psychological health. In 2014, a variety of menopausal symptoms were classified as Genitourinary Syndrome of Menopause ${ }^{[16]}$, which includes vulvovaginal atrophy in $84 \%$ of menopausal women ${ }^{[17]}$. Oestrogen insufficiency is the major cause for menopausal skin symptoms such as dryness, decreased elasticity and hydration. 17- $\beta$-oestradiol protects skin cells against oxidative stress, induces collagen production, controls cutaneous water content and the dermal thickness. Oestrogen deprivation is followed by a decrease in tissue thickness and elasticity, and a decrease in wound healing and scar formation ${ }^{[18]}$. Regarding genital changes, mucous membranes of small labia and vaginal tissue react with dryness and atrophy on low oestrogen levels ${ }^{[19]}$. Topical oestrogen application was successful in reversing atrophic changes of genital tissues ${ }^{[18]}$.

\section{Physiology of genital wound healing and scarring}

Acute wound healing

Despite constant commensal colonization of genital skin and an absent cornified layer as a potent barrier against microbial penetration, most genital wounds heal quickly and uneventfully. Communication with colleagues from gynecology or urology mirrors our observations from genital reassignment or aesthetic genital surgery. In contrast to skin of other body parts, genital wound healing is characterized by initial swelling with fast resolution and by almost invisible scarring [Figure 4].

It is a well-known fact that wound healing is promoted by a moist environment - present on mucous surfaces. Furthermore, inapparent scarring might be due to the fact that abundant elastic fibers are present in genital skin compared to normal skin and to the absence of tissue tension due to lack of fixation to underlying bone or cartilage. The disadvantage of the absent attachment to skeletal structures of genital skin is its tendency to shrink when a chronic inflammatory stimulus is present [Figure 3].

\section{Influence of microbial colonization}

Surfaces of mucous epithelia are inhabited by a microflora that differs from normal skin as well. Despite the missing cornified barrier and abundant commensal habitation, genital infections are rare (as in the oral cavity) but in the event of bacterial penetration, infections can be disastrous with high mortality. One example of a life-threatening genital infection is Fournier's gangrene that can only be cured by extensive and deep debridement of infected skin and underlying tissues as well as antibiotic therapy ${ }^{[3]}$. Constant exposure to commensal microbia is reflected by differential cellular immune responses with higher expression of antimicrobial peptides (AMPs) and defensins. The immune response and resolution are fast with conversion of M1 to M2 macrophages and reduced expression of pro-inflammatory cytokines ${ }^{[15]}$. Upon injury, skin cells increase IL-1 $\alpha$ production 15 -fold in comparison to vaginal epithelial cells which show only a 3 -fold increase. IL- $1 \beta$ and TNF- $\alpha$ are secreted by cutaneous epithelia in contrast to mucous epithelial cells ${ }^{[20]}$. With regard to pro-fibrotic mediators, transforming growth factor (TGF)- $\beta$ is significantly elevated in normal skin keratinocytes but not in mucosal epithelia and without induction of fibrotic processes in the underlying connective tissue. In summary, the reduced inflammatory response of mucosal epithelia to injury ensures fast wound closure. 


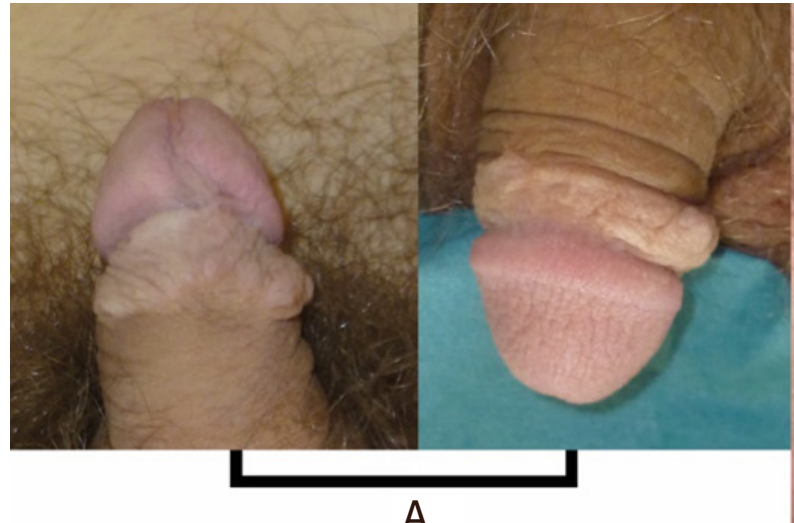

A

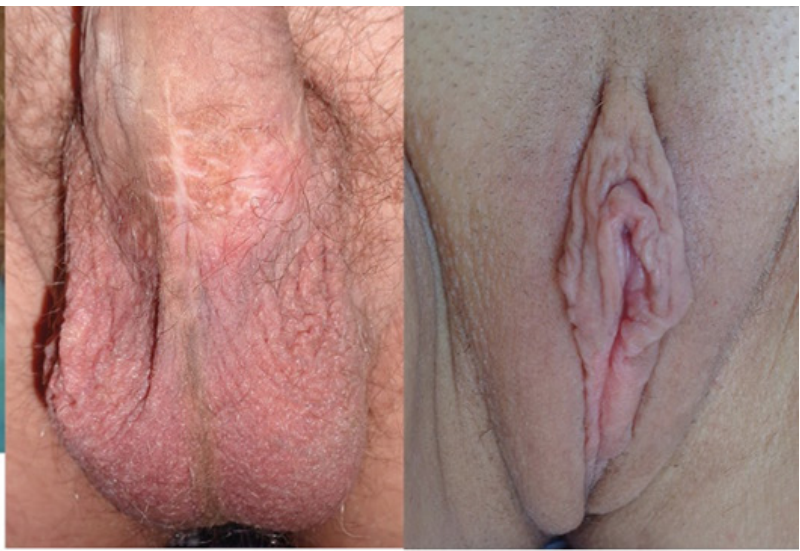

B
C

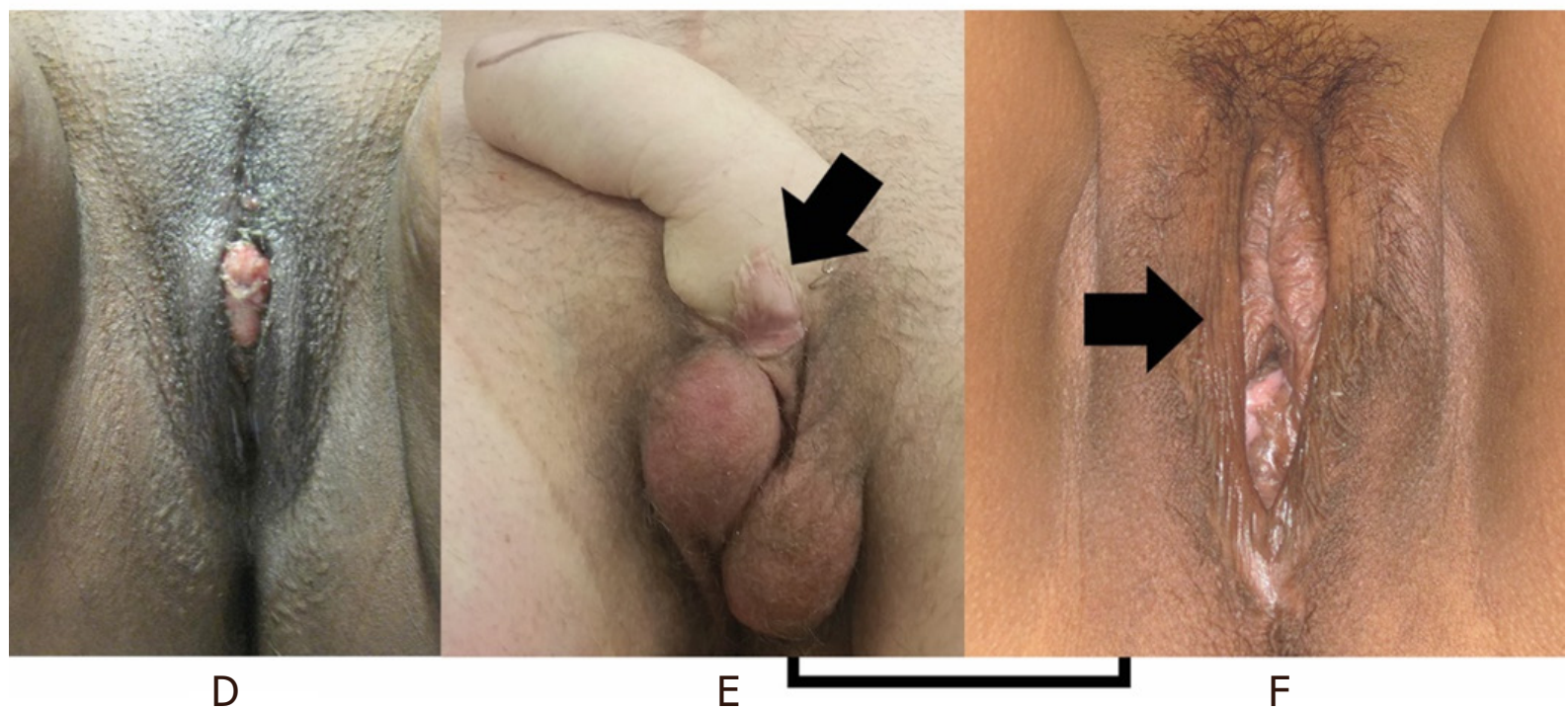

Figure 4. Clinical examples for genital scarring in male and female genitalia. A: almost invisible scar after circumcision. Note color differences between the inner and the outer part of the foreskin; B: scrotal scarring after massive trauma and scrotal reconstruction; C: invisible scarring after esthetic reduction of the small labia; D: scarring seen in FGM/C after reconstructive surgery; E, F: scarring after gender reassignment surgery: E: female-to-male gender reassignment with scarring between the clitoridal insertion sutures into the penoid (arrow) which was performed by a thigh flap; F: male-to-female gender reassignment situs with almost invisible scarring (arrow) seen on the big labia (constructed out of scrotal and penile skin)

\section{Pathophysiology of chronic genital repair processes}

\section{Foreign body granuloma}

Many different substances are in use for penile enlargement, e.g., vaseline, paraffin, liquid mercury, silicone, or cod liver oil. A chronic inflammatory reaction due to foreign bodies was followed by granuloma formation, infections, swelling, and local tissue necrosis ${ }^{[21]}$. Polymethylmethacrylat microspheres, autologous fat or silicone implants are approved in certain countries for penile enlargement surgery ${ }^{[22,23]}$. The placement of permanent, alloplastic foreign body material in an environment populated by a variety of commensal microbes is risky due to the inherent danger of infection. In case of granuloma, tissue necrosis or implant infection, the foreign material must be removed with subsequent tissue loss. Foreign body materials can initiate a chronic inflammatory process with subcutaneous tissue fibrosis leading ultimately to a shrinkage of the entire penile shaft or to massive epitheloid cyst formation as seen in women after FGM/C. Of note, tissue shrinkage occurs in the subcutaneous compartment rather than in the penile shaft skin. 


\section{Autoimmune diseases}

Lichen sclerosus et atrophicus (LSC) is the most common chronic dermatitis of the genital skin which leads to fibrosis and tissue shrinkage and atrophy. Autoimmune responses govern the histological appearance with epidermal atrophy, hyalinization of the upper dermis and immune cell infiltrate. In patients with chronic disease, sclerotization of the tissue is found ${ }^{[24]}$. LSC is found in females and males with a ratio of up to 10:1 with increased occurrence in pre-pubertal and post-menopausal women. In men, LSC is the most common cause of acquired phimosis ${ }^{[25]}$ and affects the glans and the prepuce. In chronic disease, these atrophic lesions can lead to a complete destruction of the vulva with shrinkage of the small labia and narrowing of the vaginal entrance. The patient's quality of life is severely reduced due to chronic itching and pain. LSC is associated with squamous cell carcinoma in $5 \%$ of women ${ }^{[26]}$ and up to $30 \%$ of men ${ }^{[25]}$. Another related dermatosis, the Lichen planus, presents with similar symptoms and aetiology which makes the initial differentiation between Lichen sclerosus and Lichen planus difficult ${ }^{[27]}$. Finally, patients suffering from Behçet's or Crohn's disease may have genital manifestations of their primary autoimmune disease as well.

\section{DISCUSSION}

Abundant of knowledge is available regarding normal and pathological wound healing and scarring of skin tissue from the whole body except for the genital skin. Because the genital area is generally considered as embarrassing, patients rarely contact gynaecologists, urologists or plastic surgeons for reconstructive measures. If so, little expertise is present as reflected by the sparse literature available on genital wound healing and scarring. In the past decades, gender reassignment surgery, labioplasty, and plastic reconstructive surgery in FGM/C has been established in plastic surgery with rising awareness that genital skin pathophysiology differs from skin from other body areas.

Interestingly, hypertrophic scarring to the genitalia is uncommon even when dark skin types are considered. After circumcision or aesthetic labia reduction, almost invisible scars are the result. This phenomenon is explained by genital skin biomechanics and morphology with three key characteristics that are eminent to genital skin, namely: (1) lack of skeletal support and reduced tissue tension; (2) abundance of elastic fibers; and (3) presence of superficial cutaneous fasciae, e.g., the Dartos fascia. Tissue tension and TGF- $\beta$ are of pivotal importance for scarring and tissue fibrosis ${ }^{[2]}$. Bone and cartilage are part of skeletal structures that provide anchorage for muscles, tendons and other connective tissue structures with the skin spanning over all tissues as outer barrier. Hence, intact skin has an intrinsic, physiological tension which is released after full-thickness incisions or trauma and is visible as gaping wound edges. The human genitalia are not supported by a skeletal framework, and thus genital biomechanics differ from other body parts. The skin is loose and highly flexible - important characteristics for fast volume changes during sexual intercourse or child birth. Abundance of elastic fibres in genitalia is the prerequisite for tissue elasticity that is required for volume changes during erection. Elastic fibres are located to the Dartos fascia that is found beneath the dermis, reminiscent of the carnosus muscle found in fur bearing animals. In humans, the platysma muscle of the neck, palmaris brevis in the hand and the Dartos fascia belong to the panniculus carnosus. In pathological conditions such as buried penis or hypospadias, a significant reduction of elastic fibres and tissue elasticity is found in the Dartos fascia ${ }^{[29]}$. Furthermore, chronic genital inflammatory conditions such as LSC are characterized by decreased elastic fibres, tissue fibrosis and atrophy ${ }^{[2,30]}$. Our data show that the morphology of genital skin differs to skin from other body sites by having a thin epidermis and no fat tissue, but instead displaying a superficial cutaneous fascia (Dartos fascia in men or Colles fascia in women) with abundant elastic fibres.

In plastic surgery, tension-free wound margins are mandatory for unimpaired wound healing with almost invisible scarring. Lack of skeletal anchorage, highly elastic skin and abundance of tissue are advantageous for acute wound closure of genital skin. Interestingly, almost no scarring is found after routine circumcision 
in $\mathrm{men}^{[31]}$. After traumatic skin loss of about half of the scrotal sac, the defect can be closed primarily with the remaining scrotal tissue ${ }^{[8,32]}$. Furthermore, abundant genital tissue provides the means for various local flaps which are commonly used for scrotal and penile reconstruction ${ }^{[33,34]}$ or gender reassignment surgery $^{[35]}$.

The importance of hormones on cutaneous repair is well established ${ }^{[10]}$. Unfortunately, most studies used skin tissue from non-genital body areas with no information on performance of genital skin in wound repair. Genital skin possesses the whole armamentarium to synthesize its own sex hormones ${ }^{[36]}$ and an abundance of corresponding receptors to stimulate repair processes ${ }^{[15,37]}$. During aging, hormone levels decrease and the cytoprotective effect of oestrogens ceases ${ }^{[38]}$. Increased inflammation due to inflammatory cell recruitment, matrix metalloproteinase secretion and tissue degradation with subsequent loss of extracellular matrix are the cause for generalized tissue atrophy including genitalia with loss of elasticity ${ }^{[15]}$. In post-menopausal women, oestrogen deficiency is followed by vulvar and vaginal dryness and atrophy that can be - in part - reversed by local or systemic hormone replacement therapy ${ }^{[39]}$.

Chronic inflammatory diseases such as LSC lead to tissue fibrosis with epidermal thickening and to a shrinkage and atrophy with complete tissue destruction of the outer genitalia in the long-run. Interestingly, excessive scarring is rarely found in genitalia but atrophy and shrinkage is. In contrast to the genital skin, hypertrophic scarring and scar contractures are frequently seen after trauma or burns in body areas adjacent to the genitalia, e.g., the groin or the perineal crease ${ }^{[31]}$. A novel and seemingly successful approach to tackle LSC in women was published by Italian gynaecologists who used autologous lipofilling for vulvar atrophy ${ }^{[40]}$. Fat grafts are known for their pain-reducing and anti-inflammatory properties ${ }^{[41,42]}$. Aside from immunological effects, the fat graft restores the volume of vulvar structures and changes biomechanics as well $^{[43,44]}$.

The presence of mucous epithelia characterizes not only genital skin but also the oral cavity. As stated above, little data is available on genital mucosal wound repair but abundant knowledge on oral mucosal cell behaviour is, which might be comparable for both body parts. Like oral wound repair ${ }^{[45]}$, genital wounds heal faster, with less scarring and faster resolution of the inflammatory response compared to normal $\operatorname{skin}^{[46]}$. An important observation was the diverging angiogenesis between oral and normal skin. Oral wounds develop less but functional vessels for wound tissue revascularization in contrast to abundant immature capillaries in granulation tissue of normal skin ${ }^{[47]}$. Unfortunately, no data is available on angiogenesis in genital wound repair.

Faster wound repair of oral keratinocytes was attributed to higher proliferation rates, faster migration and independence from paracrine stimuli by underlying connective tissue cells ${ }^{[48]}$. Seemingly, the epithelial response to injury governs the local inflammatory reaction and subsequently scar formation by the underlying dermal tissue. In previous studies it was shown that vaginal epithelium responds to injury with less IL- $1 \beta$ and absence of TNF- $\alpha$ secretion in comparison to skin keratinocytes with reduced scar formation ${ }^{[20]}$. Similar effects were found upon IL-1 $\beta$ stimulation with higher levels of IL- 6 and TNF- $\alpha$ in epidermal compared to oral keratinocytes with faster wound closure implying a robust responsiveness of mucosal cells to inflammatory stimuli ${ }^{[49]}$. Further research on genital tissue is needed to verify if findings from the oral cavity correspond to genitalia as well.

Barrier epithelia are constantly exposed to the commensal microbial flora and elicit differential immune responses to continuously present bacteria in contrast to localized infections. Moreover, genital epithelia face exposure to foreign microbia during sexual intercourse. AMP such as defensins belong to the epithelial repertoire of antimicrobial defence mechanisms ${ }^{[50]}$ and are physiologically secreted at low levels for protection against the commensal flora ${ }^{[51]}$. Bacterial infection with depletion of the indigenous microbial 
population initiates the secretion of proinflammatory mediators with increased and differential AMP expression in the female reproductive tract ${ }^{[51,52]}$. While $\beta$-defensin- 1 is constitutively expressed by mucosal epithelia, $\beta$-defensin-2 and -3 are found during inflammation and infection ${ }^{[53]}$. Less $\beta$-defensin-2 was found in migrating cells from a bioengineered skin construct composed of human foreskin cells in comparison to full-thickness skin graft sampled from the thigh ${ }^{[54]}$. Because foreskin derived cells are frequently used as human skin cells in experimental studies, further research is needed with comparison of cellular performance between genital and non-genital cutaneous cells.

In summary, genitalia comprise epithelial and connective tissues with varying morphology and inflammatory responses to trauma. Lack of skeletal anchorage, abundance of connective tissue with high content of elastic fibres and presence of superficial fasciae provide different biomechanics and scarring behaviour of genital skin in comparison to other body parts. Reconstructive procedures should take the characteristics of genital tissues into consideration when planning defect closure with functional restoration of micturition and sexuality. As a consequence, complex surgical interventions of the genitalia and adjacent body areas should exclusively be performed by experienced specialists, preferably in an interdisciplinary setting.

\section{DECLARATIONS}

\section{Authors' contributions}

Made substantial contributions to conception and design of the study and performed data analysis and interpretation: Mirastschijski U, Jiang D, Rinkevich Y, Karim R, Sorg H

Performed data acquisition, as well as provided administrative, technical, and material support: Mirastschijski U, Jiang D

Writing and editing of the manuscript, advice and intellectual support: Mirastschijski U, Jiang D, Rinkevich Y, Karim R, Sorg H

Editing of figures, tables and photographs: Mirastschijski U, Jiang D, Karim R

\section{Availability of data and materials}

Not applicable.

\section{Financial support and sponsorship}

Rinkevich Y was supported by the Human Frontier Science Program Career Development Award (CDA00017/2016), the German Research Foundation (RI 2787/1-1 AOBJ: 628819), the Fritz-ThyssenStiftung (2016-01277), and the European Research Council Consolidator Grant (ERC-CoG 819933).

\section{Conflicts of interest}

All authors declared that there are no conflicts of interest.

\section{Ethical approval and consent to participate}

Tissue specimens were obtained after information and written patient's consent. The study was approved by the local ethical committees (Ethics Committee of the Medical Chamber of Bremen, No. 336/12 and No. RA/RE 336; and of Bavaria, 2018-157).

\section{Consent for publication}

Written informed consent for anonymous publication of photographs are routinely obtained from every patient undergoing plastic surgery and are stored in the patients' files.

\section{Copyright}

(C) The Author(s) 2020. 


\section{REFERENCES}

1. Balzano FL, Hudak SJ. Military genitourinary injuries: past, present, and future. Transl Androl Urol 2018;7:646-52.

2. Ismail Aly ME, Huang T. Management of burn injuries of the perineum. In: Herndon D, editor. London: Elsevier; 2018. pp. 609-17.

3. Lehnhardt M, Wallner C, Daigeler A. Reconstruction of the male genitals after Fournier gangrene. In: Mirastschijski U, Remmel E, editors. Berlin: Springer; 2019. pp. 253-63.

4. World Health Organization. Male circumcision: global trends and determinants of prevalence, safety and acceptability. Geneva: IWHO Library Cataloguing-in-Publication Data; 2007. Avaliable from: https://apps.who.int/iris/bitstream/handle/10665/43749/9789241596169 eng.pdf?sequence $=1$. [Last accessed on 17 Nov 2020]

5. Mirastschijski U, Schwab I, Coger V, et al. Lung surfactant accelerates skin wound healing: a translational study with a randomized clinical phase I study. Sci Rep 2020;10:2581.

6. Correa-Gallegos D, Jiang D, Christ S, et al. Patch repair of deep wounds by mobilized fascia. Nature 2019;576:287-92.

7. Jiang D, Correa-Gallegos D, Christ S, et al. Two succeeding fibroblastic lineages drive dermal development and the transition from regeneration to scarring. Nat Cell Biol 2018;20:422-31.

8. Mirastschijski U, Schwenke C, Schwab I, Buchhorn A, Schmiedl A. Midline raphe scroti artery flap for penile shaft reconstruction. Plast Aesthet Res 2020;7:1-13.

9. Mirastschijski U, Remmel E. Intimchirurgie. Berlin: Springer Verlag; 2019.

10. Gilliver SC, Ashworth JJ, Ashcroft GS. The hormonal regulation of cutaneous wound healing. Clin Dermatol 2007;25:56-62.

11. Gilliver SC, Ashcroft GS. Sex steroids and cutaneous wound healing: the contrasting influences of estrogens and androgens. Climacteric 2007;10:276-88.

12. Pomari E, Dalla Valle L, Pertile P, Colombo L, Thornton MJ. Intracrine sex steroid synthesis and signaling in human epidermal keratinocytes and dermal fibroblasts. FASEB J 2015;29:508-24.

13. Emmerson E, Campbell L, Ashcroft GS, Hardman MJ. Unique and synergistic roles for 17beta-estradiol and macrophage migration inhibitory factor during cutaneous wound closure are cell type specific. Endocrinology 2009;150:2749-57.

14. Crompton R, Williams H, Ansell D, et al. Oestrogen promotes healing in a bacterial LPS model of delayed cutaneous wound repair. Lab Invest 2016;96:439-49.

15. Wilkinson HN, Hardman MJ. The role of estrogen in cutaneous ageing and repair. Maturitas 2017;103:60-4.

16. Portman DJ, Gass ML. Vulvovaginal atrophy terminology consensus conference p. genitourinary syndrome of menopause: new terminology for vulvovaginal atrophy from the international society for the study of women's sexual health and the north american menopause society. Maturitas 2014;79:349-54.

17. Santoro N, Komi J. Prevalence and impact of vaginal symptoms among postmenopausal women. J Sex Med 2009;6:2133-42.

18. Rzepecki AK, Murase JE, Juran R, Fabi SG, McLellan BN. Estrogen-deficient skin: the role of topical therapy. Int J Womens Dermatol 2019;5:85-90.

19. Nappi RE, Martini E, Cucinella L, et al. Addressing vulvovaginal atrophy (VVA)/genitourinary syndrome of menopause (GSM) for healthy aging in women. Front Endocrinol (Lausanne) 2019;10:561.

20. Gallant-Behm CL, Du P, Lin SM, Marucha PT, DiPietro LA, Mustoe TA. Epithelial regulation of mesenchymal tissue behavior. J Invest Dermatol 2011;131:892-9.

21. Schill S, Panfilov DE, Mirastschijski U. Intimchirurgie beim mann. In: Mirastschijski U, Remmel E, editors. Berlin: Springer; 2019. pp. 49-68.

22. Lemperle G, Casavantes L. Penisvergrößerung durch Injektion von PMMA-Mikrosphären. In: Mirastschijski U, Remmel E, editors. Berlin: Springer; 2019. pp. 79-89.

23. Lemperle G, Elist JJ, Jethon C. Penisvergrößerung mit dem penuma-silikon-implantat. In: Mirastschijski U, Remmel E, editors. Berlin: Springer; 2019. pp. 69-78.

24. Lee A, Fischer G. Diagnosis and treatment of vulvar lichen sclerosus: an update for dermatologists. Am J Clin Dermatol 2018;19:695706.

25. Clouston D, Hall A, Lawrentschuk N. Penile lichen sclerosus (balanitis xerotica obliterans). BJU Int 2011;108 Suppl 2:14-9.

26. Kirtschig G. Lichen sclerosus-presentation, diagnosis and management. Dtsch Arztebl Int 2016;113:337-43.

27. Terlou A, Santegoets LA, van der Meijden WI, et al. An autoimmune phenotype in vulvar lichen sclerosus and lichen planus: a Th1 response and high levels of microRNA-155. J Invest Dermatol 2012;132:658-66.

28. Hinz B, McCulloch CA, Coelho NM. Mechanical regulation of myofibroblast phenoconversion and collagen contraction. Exp Cell Res 2019;379:119-28.

29. Atmoko W, Shalmont G, Situmorang GR, Wahyudi I, Tanurahardja B, Rodjani A. Abnormal dartos fascia in buried penis and hypospadias: evidence from histopathology. J Pediatr Urol 2018;14:536.e1-7.

30. Canady J, Karrer S, Fleck M, Bosserhoff AK. Fibrosing connective tissue disorders of the skin: molecular similarities and distinctions. $J$ Dermatol Sci 2013;70:151-8.

31. Mirastschijski U. Genital scars. In: Téot L, Mustoe TA, Middelkoop E, Gauglitz G, editors. London: Springer International Publishing; 2020. pp. 1-640.

32. Mirastschijski U, Schwenke C, Schmiedl A. Plastisch-chirurgische rekonstruktion des männlichen genitales. In: Mirastschijski U, Remmel E, editors. Berlin: Springer; 2019. pp. 189-206.

33. Mirastschijski U. Buried penis. In: Mirastschijski U, Remmel E, editors. Berlin: Springer; 2019. pp. 107-14.

34. Mirastschijski U. Classification and treatment of the adult buried penis. Ann Plast Surg 2018;80:653-9. 
35. Schaff J, Morath S, Mirastschijski U. Operative techniken bei mann-zu-frau-transsexualität. In: Mirastschijski U, Remmel E, editors. Berlin: Springer; 2019. pp. 294-303.

36. Zouboulis CC, Chen WC, Thornton MJ, Qin K, Rosenfield R. Sexual hormones in human skin. Horm Metab Res 2007;39:85-95.

37. Choudhry R, Hodgins MB, Van der Kwast TH, Brinkmann AO, Boersma WJ. Localization of androgen receptors in human skin by immunohistochemistry: implications for the hormonal regulation of hair growth, sebaceous glands and sweat glands. J Endocrinol 1992;133:467-75.

38. Thornton MJ. Estrogens and aging skin. Dermatoendocrinol 2013;5:264-70.

39. Matthews N, Wong V, Brooks J, Kroumpouzos G. Genital diseases in the mature woman. Clin Dermatol 2018;36:208-21.

40. Boero V, Brambilla M, Sipio E, et al. Vulvar lichen sclerosus: a new regenerative approach through fat grafting. Gynecol Oncol 2015;139:471-5

41. Fredman R, Edkins RE, Hultman CS. Fat grafting for neuropathic pain after severe burns. Ann Plast Surg 2016;76 Suppl 4:S298-303.

42. Prantl L, Rennekampff HO, Giunta RE, et al. Current perceptions of lipofilling on the basis of the new guideline on "autologous fat grafting". Handchirurgie Mikrochirurgie Plastische Chirurgie 2016;48:330-6.

43. Clauser LC, Tieghi R, Galie M, Carinci F. Structural fat grafting: facial volumetric restoration in complex reconstructive surgery. $J$ Craniofac Surg 2011;22:1695-701.

44. Jaspers ME, Brouwer KM, van Trier AJ, Groot ML, Middelkoop E, van Zuijlen PP. Effectiveness of autologous fat grafting in adherent scars: results obtained by a comprehensive scar evaluation protocol. Plast Reconstr Surg 2017;139:212-9.

45. Larjava H, Wiebe C, Gallant-Behm C, Hart DA, Heino J, Hakkinen L. Exploring scarless healing of oral soft tissues. J Can Dent Assoc 2011;77:b18.

46. Mak K, Manji A, Gallant-Behm C, et al. Scarless healing of oral mucosa is characterized by faster resolution of inflammation and control of myofibroblast action compared to skin wounds in the red Duroc pig model. J Dermatol Sci 2009;56:168-80.

47. DiPietro LA. Angiogenesis and wound repair: when enough is enough. J Leukoc Biol 2016;100:979-84.

48. Turabelidze A, Guo S, Chung AY, et al. Intrinsic differences between oral and skin keratinocytes. PLoS One 2014;9:e101480.

49. Glim JE, van Egmond M, Niessen FB, Everts V, Beelen RH. Detrimental dermal wound healing: what can we learn from the oral mucosa? Wound Repair Regen 2013;21:648-60.

50. Zasloff M. Innate immunity, antimicrobial peptides, and protection of the oral cavity. Lancet 2002;360:1116-7.

51. Yarbrough VL, Winkle S, Herbst-Kralovetz MM. Antimicrobial peptides in the female reproductive tract: a critical component of the mucosal immune barrier with physiological and clinical implications. Hum Reprod Update 2015;21:353-77.

52. Lai Y, Gallo RL. AMPed up immunity: how antimicrobial peptides have multiple roles in immune defense. Trends Immunol 2009;30:131-41.

53. Chung WO, Dale BA. Innate immune response of oral and foreskin keratinocytes: utilization of different signaling pathways by various bacterial species. Infect Immun 2004;72:352-8.

54. Mirastschijski U, Bugdahl R, Rollman O, Johansson BR, Agren MS. Epithelial regeneration from bioengineered skin explants in culture. Br J Dermatol 2006;154:42-9. 